\title{
Popular Participation and Legitimacy in Constitutional Change: Finding the Sovereign
}

\author{
Bleddyn Davies ${ }^{1}$
}

Published online: 10 December 2015

(C) The Author(s) 2015. This article is published with open access at Springerlink.com

\begin{abstract}
After the Referendum on Scottish Independence, Ed Milliband called for a constitutional convention on the shape of future devolution. Underpinning this call appeared to be the assumption that existing mechanisms for securing constitutional change were not able to ensure that the people were adequately represented. This paper examines legislative amendment of the Constitution and Popular referenda as existing mechanisms for constitutional change in the UK to try and establish the role they play in the UK Constitution and whether that assumption is true. It then goes on to examine the constitutional convention as a forum for securing change. It concludes that all of these mechanisms can be seen as legitimizing in some way, and that all can play a role in securing legitimate change, but that no one mechanism can guarantee the democratization and legitimization of a system. Both legitimacy and democracy are virtues which a system may enjoy to a greater or lesser extent but the way in which a system can be amended tells us a great deal about where the true sovereign lies in a given constitutional system.
\end{abstract}

Keywords Demoracy - Legitimacy - Constitutional change · Referenda · Constitutional conventions · Sovereignty

\section{Introduction}

In the immediate aftermath of the Scottish referendum, Ed Milliband, then leader of the Labour Party, called for a constitutional convention to "to address the need for further devolution in England and political reform of

Bleddyn Davies

b.r.davies@ljmu.ac.uk

1 Liverpool John Moores University, Liverpool, UK 
Westminster". ${ }^{1}$ This, it was argued, would allow "a comprehensive and credible process involving citizens, to take forward a debate about how we are governed."2

Of course Mr Milliband lost the election which followed and this plan never came to pass, but lingering questions remain about how further devolution to Scotland will be managed and the consequences that such devolution will have for the United Kingdom and its other constituent nations. More than that though, the supposed need for a convention presumes that existing mechanisms for securing constitutional change in the United Kingdom lack the capacity to adequately involve the citizens or properly foster that debate.

This paper will examine some of the mechanisms by which constitutional change can be/has been achieved, both in the UK and elsewhere to discover the extent to which any of them can be said to be "democratic", and whether that democracy has an impact on the change which is ultimately effected. More than that though this paper will argue that neither democracy nor legitimacy are necessary components of the constitutional system, but are tools by which a constitutional framework can be judged.

At the heart of this examination, a key question emerges as to where Constitutional Sovereignty really lies in the British Political system; is it institutional or democratic? That has an significant impact on the propriety, if not the legality of the mechanisms chose to secure major changes to the constitution. It will necessarily therefore have to consider the very idea of constitutional change, and examine the roll of democracy in legitimizing the constitutional order.

\section{Constitutional Change}

First, it is necessary briefly to reflect on what is meant in this context by constitutional change. In other systems of government this might seem a strange question. Constitutional change would appear to mean no more or less than amending the constitutional text. That is not the case in the United Kingdom where we lack the single textual "capital-C" Constitution. Instead, a myriad of sources make up our constitutional system, all subject to change in different ways, although always against the backdrop of a Sovereign Parliament able to express it views on any subject at any time.

For the purpose of this piece, we shall start from Wheare's definition of the constitution as being the sum total of all of the rules which relate to the government of the State. ${ }^{3}$ That would lead us to assume that any change to the rules relating to the government of the State would have constitutional implications. While that is true, perhaps it is necessary to separate major from minor constitutional change. In

\footnotetext{
1 "A Constitutional Convention for the UK; a dynamic new political settlement for England and for Britain”. http://press.labour.org.uk/post/97885913129/a-constitutional-convention-for-the-uk-a-dynamic. Last accessed 25/6/15.

2 Ibid.

3 Wheare (1966).
} 
other words, in States with a written constitutional settlement, there would still be rules which relate to the Government and have constitutional significance, that are not contained in the Constitutional text. For example, the United States Presidential Succession Act 1947 is clearly a document of constitutional significance but was adopted by the Congress of the United States following normal legislative procedures. $^{4}$ The judicial review powers of the US Supreme Court are also constitutionally significant, but are not laid out in clear terms in the text. ${ }^{5}$ It may be then that we are not taking huge liberties by similarly differentiating in the British system between major change, of the type which would usually involve the amendment of a written constitutional text, and minor changes, which even in a written system could be achieved by other routes. This piece will not be overly concerned with the latter, but will primarily be focused on the processes for achieving the more major changes, and the legitimacy of those processes.

For the purpose of this analysis, constitutional change will be broken into two stages. The first, which will be referred to as the deliberative stage, is the formation of a given constitutional change, and the second, the adoption stage, is the point at which that change is either approved and takes effect or is rejected and does not.

It is important also to note that there are a number of ways in which Constitutional rules, even very significant ones, can be changed without majoritarian input at all. In particular in Common Law systems, judicial decisions can be an important source of constitutional law. ${ }^{6}$ In the UK in particular it seems there is an emergent line of case law which suggests a resurgence in Common Law constitutionalism, ${ }^{7}$ and it seems difficult to make an argument for any popular participation or legitimisation in that process, other than in the most indirect and technical way. ${ }^{8}$ While the role of the judiciary in shaping constitutional change is interesting and worthy of consideration, it is largely beyond the scope of this piece.

\section{Legislative Amendment}

Diceyan Parliamentary Sovereignty reminds us that Parliament may legislate on any subject of its choosing and that no person or institution created under UK law may set that legislation aside. ${ }^{9}$ This has the practical effect of allowing the UK Parliament to change our constitutional settlement simply by legislative act. ${ }^{10}$

Where a democratically elected legislature adopts a law in a representative system of government, that law is, broadly at least, considered legitimate. The

\footnotetext{
4 Although substantive questions have been asked regarding the constitutionality of the legislation. See Amar and Amar (1995-1996).

5 Marbury v Madison 5 US 137 (1803).

${ }^{6}$ See inter alia Marbury v Madison ibid, Vauxhaul Estates v Liverpool Corporation [1932] 1 KB 733, $R$ (Jackson) v Attorney General [2005] UK HL 56, R (Evans) v Attorney General [2015] UKSC 21.

7 Clayton (2015), Walker (2014).

8 See inter alia Clarke (2010), Legg (2001).

${ }^{9}$ For a detailed assessment of the doctrine in modern times see inter alia Gordon (2015).

${ }^{10}$ See inter alia $\mathrm{R}$ (Jackson) op cit n.5.
} 
people have conferred their ability to make legislative choices to their elected representatives. Thatcher and Stone Sweet model this as a process of delegation, with the constituents delegating their right to make decisions of this kind to an elected representative. ${ }^{11}$ That principal-agent model of decision making can be traced right through the political system from the individual citizen to the civil servant. Each delegation inherently involves a loss of control over the decision, and thus to a loss of agency in it, but does not compromise its inherent legitimacy. ${ }^{12}$

In the UK, Parliament is that delegate legislature. It has become the sovereign body under the constitution for a variety of historical and legal reasons, but it's claim to sovereignty now effectively rests on its democratic credentials. Ewing reminds us that:

The underlying legal principle [of the UK constitution] is the principle of parliamentary sovereignty, which is no more than a legal principle underpinning the idea of popular sovereignty, whereby the people, through their elected representatives and accountable government should be free to determine the rules by which they are governed. ${ }^{13}$

In other words, the transfer of power from people to parliament is sufficient to legitimise Parliament and then Parliament may enact such constitutional changes as it wishes as the people's legitimate representative in the constitutional structure. Parliamentary sovereignty is popular sovereignty and no further legitimacy is, therefore, required.

Here we reach our first tension. In a legal system based on Parliamentary Sovereignty, such as in the United Kingdom, it is perfectly lawful for Parliament acting alone to change the constitutional settlement. It is clear for example that the House of Commons acted entirely lawfully in imposing its will on the House of Lords in the adoption of the Parliament Act of 1949 and limiting further their veto power. ${ }^{14}$ However, does lawful propriety necessarily amount to legitimacy?

It is the nature of constitutional settlements that they distribute power in a polity and that they set the terms for their own amendment. Where a constitution is adopted by popular acclaim and confers on the people the right to change it by, for example, referenda, then it is clear that the people are the sovereign under such a settlement. ${ }^{15}$ Where a settlement comes into existence that allows a Parliament to amend it without referring the matter back the people, few would argue that this was an improper constitutional choice; surely it is down to the framers of each settlement to determine the propriety of those choices. But is it legitimate? Certainly Parliament in the UK is lawfully entitled to change the constitution without reference to the people. This makes Parliament the sovereign under the structure; not Parliament as it represent the popular will, but Parliament the institution. If Parliament, mid-term, decides to change the constitutional settlement without

\footnotetext{
11 Thatcher and Stone Sweet (2002).

12 Other models are available, see for e.g. Majone (2005), Fox-Decent (2011).

13 Ewing (2013).

$14 R$ (Jackson) op cit n.5.

15 Tierney (2009).
} 
reference to the people it is perfectly lawful for it do so. Whether that is legitimate hinges entirely on ones interpretation of legitimacy.

Bodansky has usefully attempted to define and further unpick the concept of "legitimacy". He starts from the position that legitimacy means the "justification of authority". ${ }^{16}$ He goes further breaking the concept into two further subsets. On the one hand, he identifies popular legitimacy which he argues is the popular acceptance of the exercise of power. ${ }^{17}$ On the other he identifies normative legitimacy which is conferred by the legal system in question. If a decision maker is lawfully, or for our purposes constitutionally, entitled to make a decision, then it is normatively legitimate. ${ }^{18} \mathrm{He}$ further argues that these are linked, but distinct; that there is a difference between saying that body is legitimate and that a body is accepted as legitimate. ${ }^{19}$

In the UK system it is clear that Parliament is normatively legitimate. The sovereignty of Parliament vests in it the power to make decisions on the future shape of the Constitution. ${ }^{20}$ Does that necessarily mean that Parliament is a popularly legitimate decision maker in that context? As we saw above, Ewing reminds us that Parliamentary Sovereignty can be understood as the manifestation of popular Sovereignty; that Parliament exercises its normatively legitimate power because it is elected by the people every 5 years. ${ }^{21}$ But something seems to be changing. While Parliament is still happy to enact minor change directly, ${ }^{22}$ major change, such as adjusting the voting system or devolution, has been put to the people in referenda. This could be seen as implying that Parliament's popular legitimacy to make decisions of a constitutional character is slipping. That it seems to require public endorsement of major constitutional variation is an interesting sign of a shift in the contitutional Sovereign from institutional to popular. That this shift in UK practice has been without revolution or even major public debate is interesting. Again though, that analysis presumes that referenda are capable of better "legitimizing" a decisions than legislative amendment. The next section will investigate the truth of that assumption.

\section{Referenda}

Referenda seem uniquely well placed to legitimise a given constitutional change. They involve putting a question of change to the people and getting a direct answer. Tierney has reviewed the use of referenda to settle constitutional questions ${ }^{23}$ and he argues that at the very least, constitutional referenda could be seen as transferring

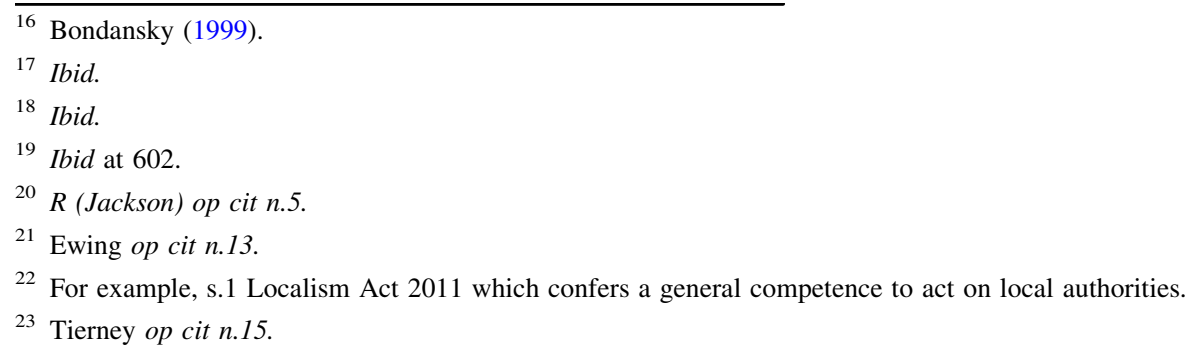


power away from the representative institutions, and towards a genuine manifestation of popular sovereignty. ${ }^{24}$ In asking the people for their view before proceeding, the organs of the State are deferring to the popular will.

This makes referenda seem incredibly appealing if one is seeking a mechanism by which the people are directly involved in changing the constitution. A question of reform is put to the public who then have a choice of whether to accept or reject it. Indeed it is not uncommon to find that constitutional systems require plebiscites to amend them. ${ }^{25}$

In practice though, the British experience of Constitutional referenda is fairly limited. Continued Membership of the European Union was put to the British people in 1975, minor reform of the electoral system was rejected in 2011, and several referenda on devolution have been held in the relevant constituent parts of the UK. ${ }^{26}$ Indeed prior to the election of the Labour government in 1997, only four referenda of this type had been conducted. They seem, however, to be coming back into vogue. As evidence of their increasingly important places in the constitution, six have been held since the Blair government was elected, with a seventh planned imminently. ${ }^{27}$

Although Referenda per se are fairly new to the UK Constitutional debate, it is possible to construct a model of British constitutional history which suggests that direct democratic involvement in constitutional change has been fairly common, and which allows a model to be constructed which lends the legislative amendments to the constitution undertaken by Victorian Parliaments to draw direct some popular legitimacy.

Victorian practice resulted in the House of Lords blocking major constitutional change. In response to that "undemocratic" obstruction, the Government would then resign and force what was essentially a single issue election on that reform. Weill describes this practice as "referendal" democracy. ${ }^{28}$ She points to a substantial body of contemporary critical theory suggesting that not only was this a well understood aspect of the operation of the Constitution at the time, but that the Lords were under a kind of constitutional obligation to force an election on the issue to ascertain the will of the people. ${ }^{29}$ Moreover, she contends that their Lordships were then under an obligation to yield to the will of the Commons on such these issues after the view of the people had been made clear. ${ }^{30}$ This equates to an early

\footnotetext{
24 Tierney, S. ibid at 363.

25 See inter alia, Article 46 of the Constitution of Ireland, Article 140 a. of the Constitution of the Swiss Confederation, Sect. 88 of the Constitutional Act of Denmark, which also requires fresh elections to be held before the amendment can be placed before the people.

26 On Scottish and Welsh devolution in 1979 and again, successfully in 1997, on the GLA and the Mayor of London in 1998, on Northern Irish Sovereignty in 1973, on the Good Friday Agreement in 1998, on Devolution in the North East of England in 2004, on devolution of power to the Welsh Assembly in 2011 and finally on Scottish Independence in 2014. There have also been numerous local referenda.

27 S.1 EU Referendum Bill (HL BILL 60).

28 Weill (2004). She cites, inter alia, The Reform Acts of 1832, 1867 and 1884 and the Parliament Act 1911 as examples of this system.

29 Weill, R. ibid at 387, see also inter alia Dicey (1893).

30 Weill, R. ibid at 388, see also, inter alia Bagehot (1896).
} 
manifestation of the Salisbury Convention ${ }^{31}$ with the House of Lords yielding to any measure which can be shown to be a key plank of the manifesto on which a Commons majority was elected. This practice made first the Lords, and then the people the guardians of the Constitution; Weill argues that this effectively created a dualist system for securing constitutional change in the nineteenth and early twentieth centuries. ${ }^{32}$ It created an institutional stage; the House of Lords reviewing the question and rejecting it, and a populist stage, by effectively forcing the Commons to put the reform to a plebiscite. There is something of an irony here in that the House of Lords was able to use its non-majoritarian position to claim effective guardianship of the will of the people on constitutional issues, by exercising its veto in a such a way as to cause their voice to be heard.

Of course the practice of using general elections as a mandate for constitutional reform is certainly not a solely Victorian practice. The New Labour election manifesto contained pledges on human rights and House of Lords reform which led directly to the Human Rights Act 1998 and the House of Lords Act 1999. Similarly, the Conservative Manifesto of 2015 contained pledges to repeal the Human Rights Act and once again to put the continued Membership of the EU to the people at some stage over the life of the Parliament.

Although referenda have not historically played a big part in British politics, in recent years the return of referenda for major constitutional questions now seems fairly settled practice. The question then becomes whether referenda are inherently better at settling constitutional questions than the representatives of the people, and do they confer any greater legitimacy upon those answers?

This section will seek to answer that question by addressing two particular issues. First, it will consider the impact that framing the question can have on the expression of popular will. Second, it will examine the consequences of defining the electorate in a given referendum. Once those issues have been considered, the section will then look at what effect staging referenda has on the constitutional Sovereign and the distribution of power in a given system.

\section{a. Framing the question}

In September 2015, during the passage through Parliament of the EU Referendum Bill the Electoral Commission published its verdict on the proposed question in clause $1 .^{33}$ The question the Prime Minister had intended to put to the people had been:

Should the United Kingdom Remain a Member of the European Union?

Voters would then have been able to vote "yes" or "no". The Electoral Commission felt that the question had the potential to influence voters. In their words:

\footnotetext{
31 Brazier (1998), Russel (2013).

32 Weill op cit n.28.

33 The Electoral Commission, "Referendum on Membership of the European Union: Assessment of the Electoral commission on the Proposed Referendum Question" (September 2015).
} 
There were two main reasons why consultation respondents and research participants viewed the question as biased-it only sets out the 'remain' option in the question, and the 'yes' response is for the status quo. ${ }^{34}$

The government heeded the Commission's advice and the question as it currently stands in clause 1 is as recommended by the Electoral commission in their report ${ }^{35}$ :

Should the United Kingdom remain a member of the European Union or leave the European Union?

\section{Remain a member of the European Union}

Leave the European Union

It is debateable whether this is any clearer, but certainly it addresses the specific concerns of the Commission that a yes vote was for the status quo. It is clear though, that the concerns of impartiality in referendum campaigning have a direct influence on the question which is asked, and as such, potentially on the outcome.

Levy identifies different issues in regards to formulating a referendum question on complex constitutional reform. ${ }^{36}$ The nature of the question framed by a constitutional referendum leads to problems;

Unsurprisingly voters often refuse to trust what they don't understand. "Don't know, vote no" is the perennial international slogan of the constitutional referendum. In the Australian Republic referendum of 1999, the Irish referendum on EU Treaty accession in 2008, the UK Alternative vote referendum in 2011 and elsewhere, such rhetoric has helped to derail elaborate and far reaching plans for constitutional reform. ${ }^{37}$

Essentially then inherent small-c conservatism appear to affect voter choices in these questions, with people tending towards the status quo unless the question presented and the outcome envisioned is extremely clear. ${ }^{38}$ On one hand, it is possible to accept this as a sensible democratic choice; 'why should we approve a constitutional change which is difficult to comprehend?' On the other as Levy observes, it reflects poorly on the state of public debate in developed democracies; "if you don't know why not become better informed?"39

Vagueness or complexity in the question also encourages voter disengagement and suspicion which can also undermine the legitimacy of the process. If the purpose of the process is to elicit popular consent to a constitutional change, and the question posed is unclear, that consent is the subject to interpretation and in the worst case, to abuse. ${ }^{40}$

\footnotetext{
34 The Electoral Commission, ibid at 39.

35 The Electoral Commission, ibid at 40.

36 Levy (2013).

37 Levy, R. ibid at 555-556.

38 For example, overwhelming Irish acceptance of a constitutional amendment in favour of same sex marriage by referendum on 22 May 2015.

39 Levy, R. op cit $n .36$ at 556.

${ }^{40}$ Levy, R. ibid at 563.
} 
Both Levy and Tierney suggest a similar approach to addressing this criticism. They argue for the introduction of so-called deliberative democracy. This is a process which encourages the genuine participation of the voting populace in a decision making process, not merely the formal act of choosing to answer yes or no to a question, but in genuinely seeking to understand the question before expressing a preference which allows, encourages and requires participants to be prepared in the course of that debate to change their minds. This elevates the process of the referendum beyond "the mere aggregation of pre-formed wills". ${ }^{4}$

Some theoretical problems with deliberative democracy have been highlighted in the literature. Principally there are differences over who needs to be involved in the deliberative stage. ${ }^{42}$ Some argue it is sufficient that the deliberations are undertaken by an elite, including politicians and judges, who are themselves democratically accountable. ${ }^{43}$ Others take the view that for a genuinely deliberative democratic process the populous at large must be involved in the process of decision making. If the former suffices for "deliberative" democracy, then the UK already reaches that standard. The elite in Parliament are capable of deliberating the problem and deferring to the people for them to affirm or reject the change. ${ }^{44}$

It seems that these two positions fit neatly with the two stages of constitutional change outlined above, that there is a deliberative stage to constitutional reform and an implementation stage. For the proponents of an 'elite' theory of deliberative democracy it is sufficient that the deliberative stage be conducted by an elite who produce a question for consultation to be decided on by the masses. For the populists it would appear that there needs to be citizen involvement in the deliberative stage as well as at the implementation stage. If popular involvement in deliberation is necessary, then obviously there is much work to do, but it is certainly not easy work.

There are practical problems with implementing deliberative democracy. Many suggestions have been made for encouraging greater deliberation including making voters read a booklet or attend a tutorial before voting. ${ }^{45}$ One possibility is presenting referenda on constitutional issues as scaled questions which outline, on the paper itself, a number of options with a brief cost-benefit analysis of each proposed model. This, it is argued, would have the advantage of encouraging genuine reflection on the options and avoid the need for an overly simplified binary question. ${ }^{46}$ Though seemingly persuasive, it needs to be remembered that even with a simple binary choice, turnout in the last UK wide constitutional referendum on the alternative voting system was $42 \%$. It is unlikely that turnout would have been increased by forcing voters to attend a mandatory seminar before voting, or that voter engagement would have been improved by presenting a complex ballot paper.

\footnotetext{
41 Tierney, S. op cit $n .15378$.

42 Tierney, S. ibid.

43 Guttman and Thompson (1997).

44 This point does not necessarily address the role of the Judiciary in the UK in securing reform of the common law constitution, but again, this is largely beyond the scope of this contribution.

45 Levy, R. op cit $n .36$ at 569.

${ }^{46}$ Levy, R. ibid at 570-571.
} 
Turnout increases dramatically when the question is clear and simple, where people can engage with it on its own terms and can see the implications it has for their day to day lives. "Should Scotland become an independent country" was rejected, in the end decisively, but here on a turnout of $85 \%$, nearly double the turnout for what was a largely technocratic question, although one with significant constitutional import. $^{47}$

It seems then that for referenda to involve the citizen in the deliberative or formative stage of constitutional reform, then we would have to think about the design of those referenda very differently and try to find practical ways of building deliberative democracy into the process. This might be extremely difficult to achieve in practice.

\section{b. Who are "the People"?}

It is easy to generalise by saying that referenda allow "the people" to decide on a question put to them. But to do so neglects a key issue with direct democracy, but who are "the people"? In deciding to stage a referendum, the State may be conferring a degree of popular Sovereignty, but in staging a referendum, the authorities need to determine eligibility to vote. By doing so the state is casting some of the population as constitutional decision makers and excluding others.

Tierney also suggests that this amounts to making certain choices about the 'sovereign' to be consulted. By choosing those eligible to vote on the question presented, a statement is made about the source of popular legitimization. In his words;

The very act of staging a constitutional referendum is itself both a declaration that a people exists and a definition of that people. ${ }^{48}$

So, for example, in the referendum on Scottish independence a choice was made about who to enfranchise. Section 2 of the Scottish Independence Referendum (Franchise) Act 2013 enfranchises anyone over 16 years of age registered as a local elector in Scotland, ${ }^{49}$ is a commonwealth citizen, an Irish citizen or a citizen of the EU who would otherwise not be barred from voting in a local election in Scotland. This has some interesting consequences in terms of defining the Sovereign whose opinion was consulted. It would include EU citizens temporarily resident in Scotland, but would exclude Scottish born British citizens who were resident outside Scotland. This means that for this purpose many who identify as Scottish, would not have been part of the constituent Sovereign. This is further complicated by the fact that Scottish secession from the United Kingdom would have been a significant constitutional change for the whole of the UK but that British citizens not resident in Scotland were excluded from that constitutional choice.

The way in which the franchise is allocated has important further ramifications. Democracy is, as we have seen above, a system which requires majoritarian

\footnotetext{
47 See also Tiereny (2015).

48 Tierney, op cit $n .15$ at 374-375.

49 Or on a young voter register established for the purpose by s.4 of that act.
} 
decision making. The direct consequence of that is that minorities are excluded from power. That is a necessary corollary of any system of democracy, direct or representative. This means that by staging a referendum on an issue which is controversial to a minority of those enfranchised we create a very real risk of imposing upon the minority something which it is clear they do not support. Tierney characterizes it thus:

The main objection is that referendums are, of their essence, inherently incompatible with the modern needs of a diverse multicultural society. In today's complex society can we really conceive of a demos able to speak as one in a sovereign act? Or does the referendum merely empower a majority to make decisions for an oppositional minority...[T]he injustice done to a minority might not only be the neglect of their political interests, but the imposition upon them of a constitutional identity that ill-fits their sense of self. $^{50}$

A good example of this problem is the controversial plebiscite held in Northern Ireland in 1973. The population of Northern Ireland were asked;

1. "Do you want Northern Ireland to remain part of the United Kingdom?" or

2. "Do you want Northern Ireland to be joined with the Republic of Ireland outside the United Kingdom?"

The result was overwhelmingly supportive of option 1, $98 \%$ of an apparently healthy $59 \%$ turnout. But of course this is only part of the story. Northern Ireland had a substantial minority catholic population, and contemporary analysis of that referendum indicate that only $1 \%$ of that population turned out to vote. ${ }^{51} \mathrm{~A}$ boycott of the poll had been organised by the main Republican parties in Northern Ireland, ostensibly to avoid violence, but it threw the legitimacy of the vote into question.

In short then, it's too simplistic to say that that referendum gives the people a choice without examining who is consulted. Of course it allows the franchisees to give an answer, but choosing who to enfranchise is a difficult and occasionally controversial decision which can significantly weaken the legitimacy of outcome.

\section{c. Referenda and legitimacy of change}

Staging a referendum is therefore not straight-forward, what is asked changes the nature of the debate, and who is asked has significant implications for defining the Sovereign in the constitutional system.

The difficulty with referenda as practiced in the UK is that they directly legitimize only one part of the process of constitutional change. The question is set by an elite, albeit under the watchful eye of the Electoral Commission. The people are then given

\footnotetext{
50 Tierney, S. op cit $n .15$ at 380 .

51 http://news.bbc.co.uk/onthisday/hi/dates/stories/march/9/newsid_2516000/2516477.stm. Last accessed $15 / 9 / 15$.
} 
a choice on that question which has been boiled down to a simple binary. As Levy notes, this degree of simplification may not always be desirable in the context of complex, far reaching constitutional questions. While some form of deliberative democracy may be an answer to that, it is practically very difficult to achieve. ${ }^{52}$

Referenda, particularly with a yes or no binary question, do not seem suited to the task of presenting constitutional change to the populace. If we accept deliberative democracy as a laudable goal, then referenda are not the solution, or are at best, only a very small part it. While referenda appear to be good at what they do; legitimizing the implementation stage of reform, or at the very least of giving the appearance of that legitimacy, they may in fact merely force us to boil down nuanced, far reaching reform to a common denominator question which is ill suited to the purpose and discourages voter participation. On the other hand there are some questions to which they may be more well suited, and can encourage voter participation.

Bogdanor suggests that the recent resurgence of referendal politics can be explained in a different way. ${ }^{53} \mathrm{He}$ argues that we are seeing a return to nineteenth century ideas of liberal constutionalism which could result in us moving away from a constitutional state towards what he terms a "popular constitutional state" which returns political and legal sovereignty to the people themselves. ${ }^{54} \mathrm{He}$ does however acknowledge that there are practical difficulties in achieving such a reimagined state based on the unwillingness of the populous to participate in such decision making mechanisms. He advocates opening up the political system in a number of ways to overcome these problems, including proportional electoral systems, increased use of referenda in non-constitutional contexts to encourage participation in actual legislative decision making and the use of citizen assemblies and constitutional conventions. ${ }^{55}$ With this in mind then, this paper will examine constitutional conventions, of the kind proposed by Mr Milliband, to try to assess whether they can assist with legitimating the deliberation stage of reform, and thus confer greater legitimacy on the whole process of constitutional change.

\section{Constitutional Conventions}

For the purposes of this piece, the term "Constitutional Convention" is used to describe a gathering of interested parties with a mandate to examine existing constitutional arrangements and to propose reforms to them. ${ }^{56}$ This definition would encompass the meeting or series of meetings of the kind envisioned by Ed Milliband in his post-referendum call. Milliband clearly imagined that such conventions would

\footnotetext{
52 Levy, op cit n.36.

53 Bogdanor (2006), Chapter 12 "Towards a Popular Constitutional State: Democracy and Participation".

54 Ibid at 310.

55 Ibid at 302 et seq.

56 As opposed to the customary practices with normative effect that shape constitutional practice in UK law.
} 
reach out beyond the normal political elite, and involve a range of stakeholders in the political process, including, one can only presume, laypersons.

There are examples of this kind of constitutional process historically, and on occasion theoretically, in a number of constitutional contexts, but they seem to be returning to constitutional vogue in recent years. This move towards a more direct involvement of persons from outside the "political classes" can be seen as giving some credence to the role that the "ordinary" citizen should play in redesigning the fundamental contract between them as a constitutive sovereign and the machinery of government.

As these systems are largely alien to the UK experience a number of examples of this kind of structure in other constitutional systems need to be examined. The formation of these conventions will be considered in order to test their democratic credentials, secondly the kinds of questions they were asked, and the kind of answers they give will be examined. Finally this section will look at the ways in which those answers are then used to implement reform. ${ }^{57}$

\section{a. The United States}

The Constitution of the United States of America was written by a Constitutional Convention in Philadelphia in 1787. Not only that, but Article V of that constitution allows for possible amendment by a similar mechanism, so as to provide the possibility of circumventing a Congress reluctant to propose amendments deemed necessary by the States. ${ }^{58}$ An important preliminary point to note is that such an amending convention has never been called, and as such there has been no judicial consideration of that provision. As a result, any discussion on the nature and form of such a convention is somewhat speculative at this stage, but there has been considerable academic debate.

The salient wording in Article $\mathrm{V}$ provides that:

on the application of the legislatures of two thirds of the several states, [Congress] shall call a convention for proposing amendments, which [...] shall be valid to all intents and purposes, as part of this Constitution, when ratified by the legislatures of three fourths of the several states, or by conventions in three fourths thereof.

In other words, when petitioned to do so by, currently, 34 States, the congress would apparently be obliged to summon an amending convention. Interestingly, the Constitution is silent on the composition and remit of any such convention and so how delegates would be selected, and in what numbers is far from clear. Presumably, the United States Congress, as the body required by Article V to call the convention would have power to determine those questions. ${ }^{59}$ It's probably also worth noting that given the contentious political issues at stake in such a convention,

\footnotetext{
57 Although space precludes analysing all of them.

58 Kauper (1968), Colon-Rios (2014).

59 Although such determination would presumably have to be made subject to the 14th Amendment.
} 
attempts to judicially review any Congressional decision on that basis would be almost inevitable. $^{60}$

Specific questions as to the remit and operation of these conventions aside, ${ }^{61}$ the process created by the Constitution does tell us some interesting things about the nature of the Constitutional sovereign in the United States. First, it is clear that the Congress performs a key role in recommending amendments to the "several States". It either adopts those amendments itself, ${ }^{62}$ or it calls the convention which will propose those recommendations. Congress, it seems, would also be free to stipulate the process for appointing, or possibly electing, delegates to such a convention. Whether congress would have the power to set the remit of such a convention remains a moot point, although it is frequently argued that it is unlikely. ${ }^{63}$

It is clear enough from either mechanism under Article $\mathrm{V}$ though, that the constitutional Sovereignty lies with the States themselves. Whether the recommended amendment comes from Congress or a convention called by it at the behest of States, it is for the States to determine whether the Amendment is accepted. Although Congress is free to stipulate whether the States should ratify any proposed amendment by act of State Legislature or by yet a further type of Convention. Presumably this is to allow Congress to circumvent recalcitrant legislatures at the State level, in the same way as the Amending Convention procedure is intended to allow States to circumvent Congress at a federal level. One way or another, the states are the constitutive Sovereign, capable of approving or rejecting proposed amendments. The citizens of the USA are of course capable of holding their State Legislatures to account electorally for decisions of which they disapprove but the constitutive function seems clearly to remain with the states. It is difficult to determine whether calling an amending convention would improve the democratic credentials of any change in the US Constitution. So much hinges on the way in which delegates would be nominated, and in fact what delegates are empowered to discuss. If each State is able to appoint its own delegates, then the democratic credentials of the delegates would likely vary from state to state. Again, it seems, the more pertinent question for analysis at the federal level is where does the Constitution place sovereignty, rather than how democratic are the mechanisms. Sovereignty is with the States, embedding democracy in that process depends on how the States choose to exercise that Sovereignty. Until the Supreme Court has cause to rule on the interpretation of Article V, which it no doubt will the very moment it is engaged, then this largely remains an academic discussion.

\footnotetext{
${ }^{60}$ Again however the US Supreme Court has been reluctant to interfere with Congress' determination of what it terms political decisions, see inter alia Coleman v Miller 307 US 433 (USC), Kauper, P. op cit. n.58, Ervin (1968).

61 On that see inter alia Rodgers (2007).

62 Per the remainder of the text of Article V.

${ }^{63}$ See inter alia, Rodgers, J. op cit n.61, Van Sickle and Boughey (1990).
} 


\section{b. Australia}

Another interesting case study on constitutional conventions is the Australian experience of 1998. Australia has some history of constitutional conventions. In the 1890s a series of Conventions met with the intention of drafting a Constitution which was eventually approved by a series of referenda. An amending convention was held in 1978 with delegates appointed by State and Federal Legislatures which proved unable to meet any of its stated aims and is recorded as an historical failure. $^{64}$

In 1998 a fresh convention was convened to consider, in particular, the future of the status of Australia as a Constitutional monarchy. The Convention was made up of 152 delegates of whom half were appointed, representatives from one or other House of the Australian Federal Parliament or from the State legislatures. The remaining delegates were drawn from the citizenry at large based on volunteers selected by a postal ballot. ${ }^{65}$ That is an understandable approach, but it does have a draw back. The only people likely to volunteer for election to a Convention of this nature are the politically engaged. These are the kinds of citizen who routinely make their voices heard both via the ordinary democratic process ${ }^{66}$ and through other means.

One might naturally expect that a Constitutional convention, which draws together a range of stakeholders including private citizens, might be expected to produce a greater "buy-in" to the proposed reform by the public at large. Again, one might expect that if the reforms are then put to a plebiscite, there would be a higher likelihood of a positive response. In fact, that is not always the case.

The Convention was dogged by infighting amidst the republican delegates who were largely unable to settle on a coherent message. ${ }^{67}$ In the end, while a proposal was presented to the people by referendum, it was rejected. There are numerous reason for hat rejection, which bear analysis by political scientists but are largely beyond the scope of this contribution. ${ }^{68}$ What it does suggest however, is that the process of staging a convention, even one which involves ordinary citizens in the formation stage of constitutional change, does not guarantee any buy into the implementation stage. A proposal which is partly drafted by an assembly of the people is not necessarily more likely to be accepted by the people at large.

\section{c. Ireland}

Another model which will be investigated here is that of the Convention on the Future of the Constitution of Ireland established by the Irish coalition government elected in 2011. Like the Australian model, it was felt there was a need to include the existing political classes in the Convention, while allowing for the popular voice

\footnotetext{
64 Ward (1995).

65 Higley and McAllister (2002).

66 Although it is probably worth noting here that voting is compulsory in Australia.

67 Higley, J and McAllister, I. ibid at 849.

${ }^{68}$ Higley, J and McAllister, I. ibid at 850 et seq.
} 
to be heard in it. In the end, the model chosen was 33 legislators, and 66 private citizens along with an independent chair. Unlike the Australian model which required self-selection among the citizenry, the Irish model selected its participants at random using the electoral register. ${ }^{69}$

That decision is interesting because it allows those who are not generally politically engaged to participate in the constitutional reform process, allowing "ordinary" citizens to express their views on Constitutional change, and ensuring a buy-in from a more genuinely reflective cross section of society. ${ }^{70}$

When we consider the outcomes of the Irish process we see more success, but still a mixed bag. The Government was committed to respond to the reports of the Convention, making the political elite the final arbiter of whether Convention proposals would be presented to the public in their role as Constitutional Sovereign. To date, two reforms proposed have been submitted to referenda which were held on the same day. One, a comparatively minor amendment to the constitution to reduce the minimum age allowed for Presidential candidates was rejected. A second, apparently more controversial, proposal to amend the constitution to allow for same sex marriage was approved. As to what this tells us about public attitudes towards reforms proposed by convention, it is extremely difficult to say, not least because it is still relatively early for detailed political or psephological analysis to have been conducted. Certainly though it reiterates the above point, that we cannot draw any assumptions as to perceived legitimacy simply by virtue of the fact that a proposal was recommended by a convention including private citizens.

Perhaps what is more interesting is the role of the Irish government as gatekeeper. The convention recommended reducing the voting age from 18 to 16, and after initially committing to stage a referendum on the question, the government reversed its decision so that other referenda could take priority. ${ }^{71}$ Otherwise, various recommendations of the Convention were accepted ${ }^{72}$ or rejected $^{73}$ and decisions are still to be taken regarding a great many others.

It was unclear from the establishment of the Convention what the government would do with the recommendations. Early in its life there were encouraging signs that the government would cooperate and refer as many of the Convention's recommendations to plebiscite as possible. However, the recanting on the promise of a referendum on reducing the voting age signalled something of a shift in governmental attitudes towards a more non-committal response. A number of referenda have been promised, for example on amending the Constitutional prohibition of blasphemy by replacing it with a ban on inciting religious hatred, but

\footnotetext{
${ }^{69}$ Resolution of the Houses of the Oireachtas July, 2012 available here: https://www.constitution.ie/ AboutUs.aspx. Last accessed 15/9/15.

70 On the methodology used in the selection process see the explanatory documents available here: https://www.constitution.ie/Documents/BehaviourAndAttitudes.pdf. Last accessed 15/9/15.

71 See confirming the referendum, Dail Eireann Debates vol 812 no. 2 at 21, and rescinding it Dail Eireann Debates vol 863 no. 1.

72 Establishing an electoral commission for example.

${ }^{73}$ For example, increasing the size of the Irish Lower House, and lengthening the term of office of the President.
} 
no date has been set, and it is likely now that no referendum will be held before the next general election. ${ }^{74}$

The Irish Convention seemed to have involved the people at both stages of the process. The creation of the Convention gives them a role at the deliberative stage of Constitutional change. The constitution itself, by requiring a plebiscite before amendment has always given the people the final say at the implementation stage. What is interesting is that the government has retained for itself a gate-keeping role between the two and it appears to be prepared to use it.

As to whether the employment of a convention model actually improves the democratic credentials of constitutional reforms, it probably does, even if only superficially by allowing a popular role at the first stage of change. Unless the Convention is itself empowered to make that change to the law, there will still be another stage in the reform process which may or may not be democratic, and may or may not be necessary to legitimate the change, and the Irish experience tells us that the role of the executive in bridging those two stages is also worthy of analysis. These examples are all different. They are all composed differently, with different rules relating to the outcome of the conventions and the adoption of the changes they recommend. Again, they are trying to democratize the process of constitutional change, but none of them appear to succeed entirely. What they can do, is help us to identify the true position of Sovereignty in the system. In the US it seems Sovereignty rests with the States. In Ireland, the Governments gate keeping role appears to keep the Sovereignty in the hands of the Elite. The Australian model seems to be the clearest attempt to genuinely devolve sovereignty to the people, but again it was fraught with problems and perhaps did not ultimately result in the outcome one would expect.

\section{Democracy, Sovereignty and the Constitution}

As with the other great pillars on which modern constitutional theory rests, democracy should not be understood as an end in itself. It should rather be seen as one of a number of measures against which one can judge the relative merits of one political and legal system against another. Democracy is part of the equation in the same way as, for example, the rule of law or the separation of powers. Montesquieu articulates the separation of powers as a pure theory. ${ }^{75}$ His argument is clear; where power overlaps the potential for tyrannical oppression by the state is too great. But later theorists and indeed architects of government systems have acknowledged, rightly, that the pure separation of powers is impossible, and indeed that allowing some degree of overlap in a system ensures that each branch of government can guard against an of the others becoming too powerful. ${ }^{76}$

\footnotetext{
74 it Dail Eireann Debates, 20/1/15 p 22, available http://oireachtasdebates.oireachtas.ie/debates\% 20authoring/debateswebpack.nsf/takes/dail2015012000022\#N4. Last accessed 13/8/15.

75 Montesquieu (1979) Book 11, Chapter 6.

76 Madison (1788).
} 
Raz, for example, is clear that the rule of law is not an aim in itself. He reminds us that complete compliance with the principle is impossible. But it remains a tool by which the relative virtue of a legal system can be judged. ${ }^{77}$ This is further complicated by the fact that writers find it difficult to agree on the precise content of the doctrine. ${ }^{78}$ That does not mean it is not a key pillar on which a constitutional; system must rest, and a key benchmark for the virtue of such a system.

Democracy is no different. We are a long way from the city state of Athens. Pure democracy, where we all cast a vote on every decision which must be made, is not possible in a system on the scale of a modern welfare state, so mechanisms arise for ensuring a link between the people and the decision is preserved. These mechanisms have been effectively modelled by Thatcher and Stone Sweet ${ }^{79}$ as, in parliamentary systems at least, chains of delegation. These chains see our right to make government decisions delegated to a Member of Parliament who in turn delegate to a Prime Minister who delegates to Cabinet Minsters who delegate to civil servants. The fact that we do not all make collective decisions at every turn does not rob a system of it's democratic credentials, but the structures by which these decisions are or can be made are susceptible to a comparative analysis by which one can determine whether a given system is, crudely put, more or less democratic than another. ${ }^{80}$

First, it is worth remembering, that each constitutional structure will set its own terms for amendment. This confers a degree of legitimacy on any change which is properly enacted following the terms of the settlement. In a sense this can confer a kind of "meta" legitimacy on the system, although that necessarily rests on an assumption that the system was legitimately adopted in the first place. In the event that a constitution were to stipulate that a non-majoritarian body had the ability to amend the constitution of its own volition that would have to be lawfully correct, even normatively legitimate if we can return to Bodansky's labels. ${ }^{81}$ If the constitution in question is adopted by popular acclaim, conferring popular legitimacy upon it, would that change inherit a portion of that legitimacy? Does distance from the adoption of that constitution change our answer? Again, the answer to those rhetorical questions will depend on the relative weight which one gives to democracy, over, say, Raz' rule book conception of the rule of law in assessing the relative "validity" of a legal system, and no definitive answer is ever likely to be forthcoming.

That said, it can help us to understand where power lies in a constitutional structure. Parliament is clearly the Sovereign in the UK system, and whether to ask the people their views on constitutional change, or to establish a Convention for discussing such change is clearly within the sovereign competence of Parliament. They may do so, they may not. Likewise the decision to follow the popular will as expressed in such a referendum remains a Parliamentary choice. Parliament is never under a legal obligation to respond, even if the political pressures to do so would be enormous. The next changes to the powers of the devolved legislatures, for

\footnotetext{
77 Raz (1979).

${ }^{78}$ See for a masterful summary, Bingham (2010).

79 Thatcher, M, Stone Sweet, A. op cit n.11.

80 Ibid.

${ }^{81}$ Bondasnky op cit n.16.
} 
example, could lawfully be made without referenda. Likewise, Parliament could choose to put Lords reform to a plebiscite if it wished. Ewing argues there is no difference between the Institution and people as Sovereign, ${ }^{82}$ but the institution has in recent times felt it necessary to ask their electors direct questions, where they certainly were under no legal obligation to do so. That indicates a desire, or at least a perceived necessity, from the institution to redistribute some of it's sovereignty down to "the people".

\section{Conclusions}

The preceding discussion suggests that whichever path one treads for achieving constitutional change, the role of the people in that mechanism is only a part of the equation and is not determinative of that systems merits or otherwise. The question should not therefore be which mechanism confers greater validty upon constitutional change. It is clear from the forgoing analysis that the answer to that is relativistic based on the weight that one affords to competing critiques of the underlying legal system. Instead the question needs to be framed more broadly than that; how is legitimacy conferred on a constitutional system at all?

Taken to its most basic roots, the question of democratic involvement in constitutional change, whatever the mechanism by which it is achieved, fundamentally seeks to determine the sovereign in the Constitution. Representative models for constitutional change remove the choices one step from the people. In a system based on the Sovereignty of Parliament then, the rule of recognition in the constitution effectively divorces the citizen from that process. Professor Ewing argues, with some force, that in the UK at least, there is no persuasive difference between popular and institutional Sovereignty, as the institution is subject to election directly by the people. ${ }^{83}$

Clearly, however, in an era of seemingly ever increasing political disenchantment, there is an acceptance amongst the political classes that the people need to be more directly involved in constitutional discussions; referenda are a more common tool now than they have been in the past.

Referenda as a chosen solution returns sovereignty under the constitution to the people, but only in an extremely reductionist way; approve or reject a constitutional reform the complex ramifications of which are often reduced to an oversimplified binary. At the moment that process is further complicated by the fact that the choices in a referendum campaign are often being articulated by a largely discredited political class that do not, to any real extent, command the confidence of the majority of the electorate. These breed inherent conservatism and reluctance to participate.

Non-majoritarian mechanisms remain in the UK system in the form of the emergent common law constitution, but they are unsatisfactory in terms of democratic involvement, and are always potentially checked by a Sovereign legislature, although some emergent strands of judicial reasoning are suggesting that

\footnotetext{
82 Ewing, K, op cit n.13.

83 Ewing, K, op cit n.13.
} 
the Common Law will not recognise some changes, or at least work hard to restrain change that the courts do not see as being respectful of a more substantive vision of the rule of law. ${ }^{84}$

Short of revolution then, is the constitutional convention as proposed by $\mathrm{Mr}$ Milliband the key to allowing a genuine reimagining of the political sovereign under the UK constitution? Not in and of itself. Again, they allow a democratic buy into an element of constitutional change; to the formation of those changes, but they do not give any greater role to the people in implementing that change. The Irish experience indicates that calling conventions can involve people in the formation of change, but governmental gate-keeping may mean that those recommendations never bear fruit. Not only that but the Australian and Irish experiences demonstrate that change which is apparently "legitimated" in the formation stage by a convention made up of 'ordinary' citizens does not necessarily improve the buy into those reforms during the implementation stage.

No mechanism can guarantee democratic involvement in all stages, and even if it could, it is far from clear that greater direct democratic involvement leads to better change. The criteria by which we judge the virtues of a given legal system, including democracy, are little more than a set of competing interests. Pure democracy is simply not appropriate in a modern welfare state so the only question we can sensibly ask is whether the people are well represented enough in the Constitutional system that they have put in place for their government, or in the case of the UK one should more accurately say, has evolved for their government.

Again then we come back to the core point, "democracy" is a tool by which a given constitutional settlement should be judged, not an end goal. It is one of a number of competing factors. What is more compelling is the true constitutional Sovereign in the system. The use of Conventions or of referenda give us an indication of where sovereign power lies in a system and thus become useful tools of analysis. The United Kingdom in recent years has been moving towards a public dialogue in which referenda play a more important role, particularly in matters relating to constitutional change. Whether such shift in dialogue provides greater legitimacy to the system is unclear. What is clear is that whether to offer referenda or to call conventions remain questions for Parliament, and thus Parliament remains the key player in the constitution.

Acknowledgments Thanks to Gary Wilson, Nirmalla Pillay and the participants at both the symposium from which this issue was compiled and the Public Law stream at the SLSA conference 2015 for their comments on earlier drafts.

Open Access This article is distributed under the terms of the Creative Commons Attribution 4.0 International License (http://creativecommons.org/licenses/by/4.0/), which permits unrestricted use, distribution, and reproduction in any medium, provided you give appropriate credit to the original author(s) and the source, provide a link to the Creative Commons license, and indicate if changes were made.

\footnotetext{
${ }_{84}$ For example, $R$ (Jackson) v Attorney General op cit n.5, Per Lord Steyn at para 102, R (Evans) v Attorney General.
} 


\section{References}

Amar, A., and V. Amar. 1995-1996. Is the Presidential Succession law constitutional. Stanford Law Review 48: 113.

Bagehot, W. 1896. Essays on parliamentary reform. London: Kegan Paul.

Bingham, T. 2010. The rule of law. City of Westminster: Penguin Books.

Bogdanor, V. 2006. The new British constitution. London: Bloomsbury.

Bondansky, D. 1999. The legitimacy of international governance: A coming challenge for international law. American Journal of International Law 93: 596-601.

Brazier, R. 1998. Defending the hereditaries: The salisbury convention. Public Law 371.

Clarke, M. 2010. Introducing a Parliamentary confirmation process for new Supreme Court justices: Its pros and cons, and lessons learned from the US experience. Public Law 464.

Clayton, R. 2015. The empire strikes back: Common law rights and the human rights act. Public Law 3.

Colon-Rios, J. 2014. Five conceptions of constitutent power. LQR 306.

Dicey, A. 1893. A leap in the dark or our new constitution. London: John Murray.

Ervin, S. 1968. Proposed legislation to implement the convention method of amending the constitution. Michigan Law Review 66: 875.

Ewing, K. 2013. The resiliance of the political constitution. German Law Journal 14(12): 2135.

Fox-Decent, Evan. 2011. Sovereignty's promise, the state as fiduciary. Oxford: OUP.

Gordon, M. 2015. Parliamentary sovereignty in the UK constitution: Process, politics and democracy. Oxford: Hart.

Guttman, A., and D. Thompson. 1997. Democracy and disagreement. Cambridge: MIT Press.

Higley, J., and I. McAllister. 2002. Elite division and voter confusion: Australia's Republic referendum in 1999. European Journal of Political Research 41: 815.

Kauper, P. 1968. The alternative amendment process: Some observations. Michigan Law Review 66: 903.

Legg, T. 2001. Judges for the new century. Public Law 62.

Levy, R. 2013. "Deliberative voting": Reforming constitutional referendum democracy. Public Law 555.

Madison, J. 1788. The structure of government must furnish proper checks and balances between the different departments. The Federalist Papers 51.

Majone, G. 2005. Dilemmas of European integration: The ambiguities and pitfalls of integration by stealth. Oxford: OUP.

Montesquieu, C. 1979. The spirit of the law. Berkley: University of California Press.

Raz, J. 1979. The rule of law and its value. In The authority of law: Essays on law and morality, ed. J. Raz. Oxford: Clarendon.

Rodgers, J. 2007. The other way to amend the constitution. Harvard Journal of Law \& Public Policy 30(3): 1005 .

Russel, M. 2013. The contemporary house of Lords: Westminster Bicameralism revisited. Oxford: OUP.

Thatcher, M., and A. Stone Sweet. 2002. Theory and practice of delegation to non-majoritarian institutions. West European Politics 25(1): 1.

Tiereny, S. 2015. Direct democracy in the United Kingdom: Reflections from the Scottish independence referendum. Public Law 633.

Tierney, S. 2009. Constitutional referendums: A theoretical enquiry. MLR 72(3): 360.

Van Sickle, B., and L. Boughey. 1990. A lawful and peaceful revolution: Article V and congress' present duty to call a convention for proposing amendments. Hamline Law Review 14: 1.

Walker, N. 2014. Our constitutional unsettlement. Public Law 529.

Ward, A. 1995. Responsible government and recent constitutional change in Australia and New Zealand. Adelaide Law Review 15: 165.

Weill, R. 2004. We the British people. Public Law 380.

Wheare, K. 1966. Modern constitutions. Oxford: OUP. 